\title{
SPATIO-TEMPORAL CHANGES IN MORTALITY, GROWTH AND CONDITION OF THE PACIFIC OYSTER, CRASSOSTREA GIGAS, IN NORMANDY (FRANCE)
}

\author{
JULIETTE ROYER, ${ }^{1}$ MICHEL ROPERT ${ }^{\mathbf{2}}$ AND KATHERINE COSTIL ${ }^{1 *}$ \\ ${ }^{1}$ Laboratoire de Biologie et Biotechnologies Marines de l'Université de Caen (UMR IFREMER \\ Physiologie et Ecophysiologie des Mollusques Marins), esplanade de la Paix, 14032 Caen cedex, France; \\ ${ }^{2}$ Laboratoire Environnement/Ressources de Normandie, Ifremer, avenue du Général De Gaulle, \\ 14520 Port-en-Bessin, France
}

\begin{abstract}
Summer mortalities have been observed in French shellfish areas (including Normandy) since 1994, but origin of this syndrome remains unclear and is suspected to be caused by a combination of several interacting extrinsic (biotic and abiotic) and intrinsic (genetic, physiological, immunological) factors. The French research program, MOREST aimed to identify the origin of oyster summer mortality along the French coast, focusing on the interactions between oysters, their pathogens, and the environment. The present study analyzed spatio-temporal variation in growth, condition and mortality in spat, and half-grown and market-sized oysters reared from February 2000 to October 2003 at six stations within two different areas in the Bay of Veys, Normandy: Grandcamp (GR), and Gefosse (GE) that is more estuarine. These biological parameters were compared between years, age groups, and areas. Results showed that shell growth was significantly lower in the station highest on the shore and similar in the four other sites, whereas tissue growth and condition index were higher in the Gefosse area. Results also showed large interannual, interage, seasonal and spatial variation in oyster mortality. In 2001, mortalities were markedly higher than in other years and all batches and sites were affected by high mortality rates. Moreover oysters suffered much higher mortalities in their second and third years than as spat, and the difference between age classes was accentuated when mortality was high. Increases in mortality occurred when the gonad was most extensively developed and the peak coincided with the spawning and postspawning periods when gonad volume began to decrease. Spatial variability showed that mortality was higher in Gefosse than Grandcamp. Chronology and spatial variations in mortality highlighted the importance of timing and confirmed that mass mortalities may be closely linked to reproduction. The risk seems to be associated with high reproductive effort, partial spawning, and/or slow gonad resorption. Spatial variation also suggests that the study sites experience varying degrees of stress caused by biological changes and probable differences in water quality reflecting the influence of freshwater input in Gefosse where mortality is higher.
\end{abstract}

KEY WORDS: Oyster, Crassostrea gigas, summer mortality, growth, France (English Channel)

\section{INTRODUCTION}

The Pacific oyster, Crassostrea gigas is the main shellfish species reared in France, with production reaching on average 128,500 tons (CNC 2005). This species is exploited on the Mediterranean coast, in four basins along the Atlantic coast, in North Brittany and in Normandy. The production in Normandy represented on average $22 \%$ of total French production including $7.5 \%$ from the Bay of Veys. This bay is a highly productive area (Jouenne et al. 2005) which promotes rapid growth of shellfish (Fleury et al. 2003). The Bay of Veys, located in the western Bay of Seine, is an estuarine macrotidal ecosystem of $35 \mathrm{~km}^{2}$ with a catchment area of $3400 \mathrm{~km}^{2}$ including four rivers.

Since the beginning of the 1950s, abnormal mortalities of oysters have been reported throughout the world (Mackin 1961, Mori et al. 1965, Perdue et al. 1981). Along the French coastline, mass mortalities affecting oysters have been recorded during the summer period, sporadically since the 1980s and annually since the 1990s (Goulletquer et al. 1998, Soletchnik et al. 1999). Since 1994, summer mortalities have been observed in the Bay of Veys where adult losses reached $35 \%$ in 1997 and $51 \%$ in 1998 (Fleury et al. 2003). Some mortality events were caused by pathogenic epizooties (Le Roux et al. 2002), and others were attributed to extreme temperature (Mackin 1961). However, the origin of summer mortality syndrome remains unspecified and is suspected to be the result of a combination of several interacting extrinsic (biotic and abiotic) and intrinsic (genetic, physiological, immunological) factors. High temperature or

\footnotetext{
*Corresponding author. E-mail address: katherine.costil@unicaen.fr
}

salinity is known to induce or increase mortality in oysters (Lipovsky \& Chew 1972, Calvo et al. 1999). Physiological disturbances were reported to be implied in mortality, associated with low energetic status and sexual ripeness (Mori et al. 1965, Perdue et al. 1981, Cheney et al. 2000, Soletchnik et al. 2005). Aquaculture practices, pathogens and pollutants were also suspected to be involved in occurrence of summer mortalities (Goulletquer et al. 1998). In France, the mortality of commercial populations is still poorly understood and the relative contribution of potential causative factors remains largely unknown, particularly the environmental and physiological stressors that initiate mass mortalities.

A French research program, MOREST (MORtalités ESTivales), was initiated in 2001 to identify the origin of summer oyster mortality along the French coast, focusing on the interactions between pathogens, host, and environment. For this program, the Bay of Veys was chosen as an experimental site, along with Auray (south Brittany), and the Marenne-Oléron basin (Bay of Biscay).

The present study analyzes spatio-temporal variations of growth, condition and mortality of spat, juveniles (half-grown), and market-sized oysters reared at six stations within the Bay of Veys from February 2000 to October 2003. These biological parameters are compared between years, age groups, and areas. We additionally investigate relationships between oyster mortality and growth characteristics for the different stations and age groups to detect risk factors. Finally, by comparing hydrological features of the stations, the effect of potential environmental stresses on mass mortality is discussed. 


\section{MATERIALS AND METHODS}

\section{Study Sites}

The study was carried out in the Bay of Veys located on the French coast of the English Channel (Normandy, France). This intertidal area includes large oyster leasing grounds $(130 \mathrm{Ha})$. Oysters were studied at six selected stations (Fig. 1), within a farming area, which is characterized by different physicochemical conditions (Costil et al. 2005). Grandcamp area, including the farthest points from the estuary (GR1 and GR2) is very little influenced by fresh water, whereas the Gefosse area, including the three sites GE1, GE2, and GE3

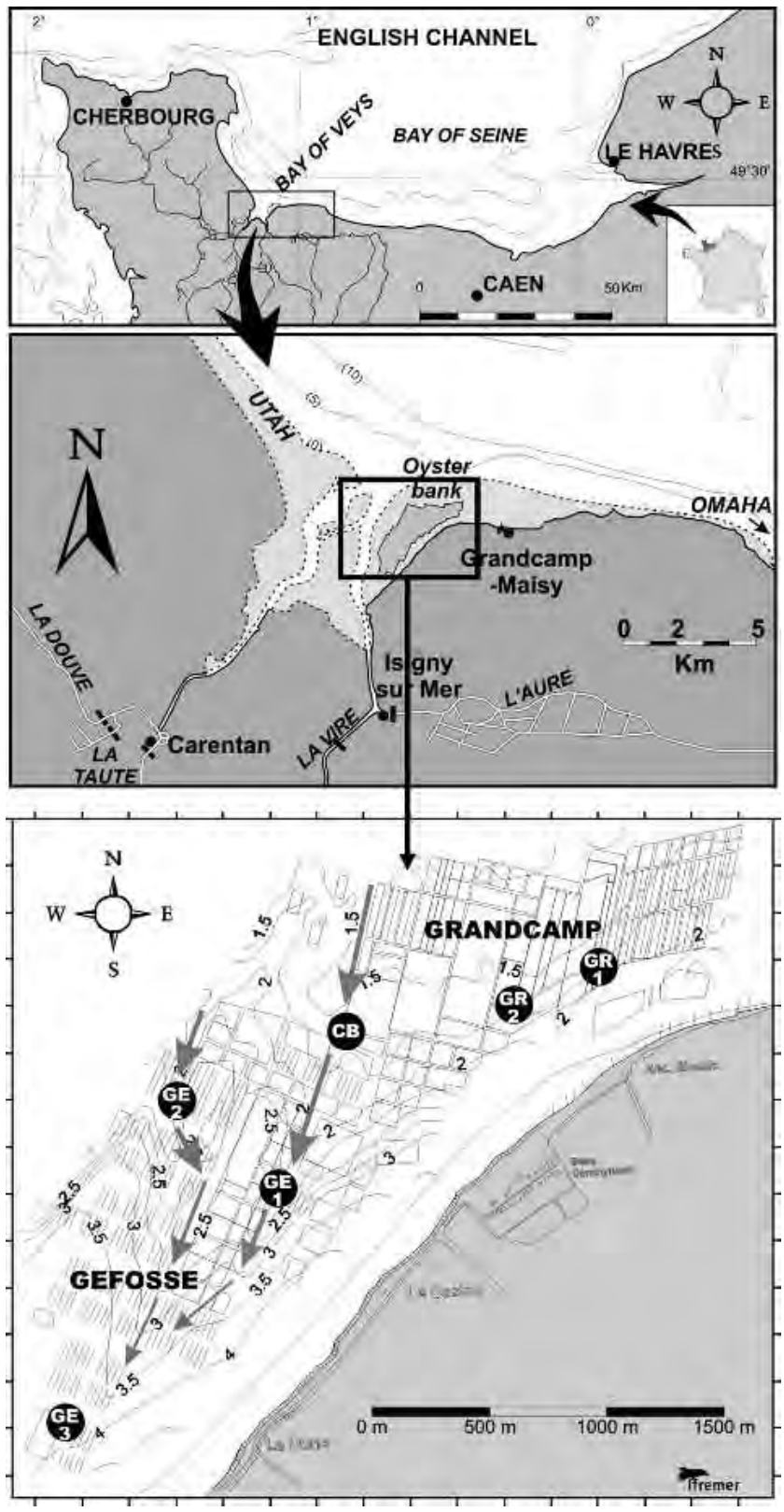

Figure 1. The study area in the Bay of Veys, and the 6 sampling stations. Arrows indicate the two "filling channels" (one near GE2 and the other close to CB and GE1) through which water comes to the shellfish culture area at the beginning of flood tide. (the highest point on the foreshore) is affected by fresh water and seawater. The substrata are heterogeneous, including rock at GR1 and GR2, and mud and fine sands at the 3 Gefosse stations and $\mathrm{CB}$, the study site located in the center of the bay.

Oysters

The experimental oysters were reared off-bottom in culture bags on iron tables, in exactly the same manner as commercially-grown oysters. At each site, 2 batches were deployed, in February 2000 (Batch B) and in February 2001 (Batch C). From these batches, culture bags of 185 oysters were constituted, except for 3 half-bags, which were filled with 100 individuals each for monitoring of mortality. Batch B came from a hatchery and consisted of 7,500 spat ( 9 mo old) with a mean initial weight of $0.98 \pm 0.27 \mathrm{~g}(21.16 \pm 3.24 \mathrm{~mm})$. Batch $\mathrm{C}$ came from a natural spatfall and consisted of 7,000 oysters ( 7 mo old) with a mean initial weight of $0.98 \pm 0.31 \mathrm{~g}(19.82 \pm 3.32 \mathrm{~mm})$. Both batches were monitored from the spat stage (corresponding to their first year of life) until their mean marketable size $(>61.24 \pm 22.13 \mathrm{~g} ;>86.10 \pm 14.42 \mathrm{~mm}$, corresponding to their third year of life).

\section{Field Sampling and Mortality Monitoring}

At the six stations, the progression of oyster mortalities was followed by means of semimonthly to monthly field observations using the triplicate half-bags. The original density of each half-bag (100 individuals) was maintained by replacing animals removed with others stockpiled in nearby bags, planted at similar densities. Mean Daily Mortalities (MDM) were assessed using the formula (Frontier 1993):

$$
\mathrm{MDM}=\frac{\operatorname{Ln}\left(\mathrm{N}_{\mathrm{ti}}\right)-\operatorname{Ln}\left(\mathrm{N}_{\mathrm{ti}}-\mathrm{Nd}_{\mathrm{ti}}\right)}{\left(\mathrm{t}_{\mathrm{i}}-\mathrm{t}_{\mathrm{i}-1}\right)} \times 100
$$

where Nd represents the number of dead or moribund oysters, $\mathrm{N}$ the number of (live) oysters at the beginning of the interval and $\left(t_{i}-t_{i-1}\right)$ the interval between 2 successive counts.

Cumulative mortalities (CM) were then calculated using the following equation:

$$
\begin{aligned}
\mathrm{CM} & =100-\mathrm{S}_{\mathrm{ti}} \\
\text { with } \mathrm{S}_{\mathrm{ti}} & =\mathrm{S}_{\mathrm{ti}-1}-\left(\mathrm{S}_{\mathrm{ti}-1} \times \frac{\mathrm{Nd}_{\mathrm{ti}}}{\mathrm{N}_{\mathrm{ti}}}\right)
\end{aligned}
$$

where $\mathrm{S}$ is the survival rate and the subscript $t_{i}$ is the date of sampling.

Mortality was followed from February 2000 to December 2002 for batch B and from February 2001 to October 2003 for batch $\mathrm{C}$.

At each 5 stations (GR1, CB, GE1, GE2, and GE3), 30 oysters per batch were randomly sampled monthly to bimonthly and analyzed in the laboratory to evaluate their biological performance. Sampling was conducted during the periods July 2000 to August 2002 for batch B and July 2001 to August 2003 for batch C.

\section{Biological Measurements}

In the laboratory, oysters were cleaned of mud, scraped to remove any attached epifauna, and weighed to the nearest $0.01 \mathrm{~g}$ to determine whole weight (WW). Shell length (SL), width (w) and thickness (T) were measured to the nearest 
$0.01 \mathrm{~mm}$ using a vernier caliper. Each oyster was then opened and soft tissue was examined for the allocation of a macroscopic index of "Sexual Maturity" (SMI). Stage 0 was attributed to thin oysters, 0.5 to partially thin oysters (with digestive gland partially visible), 1 to fleshy individuals (digestive gland hidden by the gonad), 2 to ripe oysters (which seem "veined"), and 1.5 to postspawning oysters or oysters in the process of gonadal resorption (tissues appearing heterogeneous) (Costil et al. 2005). Wet meat was weighed (WMW) and then dry meat weight (DMW) was determined after freeze-drying for a minimum of $48 \mathrm{~h}$. Finally, shell valves were weighed after drying in an oven for $24 \mathrm{~h}$ at $60^{\circ} \mathrm{C}$.

For shell and soft tissue, growth rates between the sampling dates were calculated using the general formula:

$$
\mathrm{GR}=\frac{\left(\operatorname{lnWt}_{2}-1 n \mathrm{Wt}_{1}\right)}{\left(\mathrm{t}_{2}-\mathrm{t}_{1}\right)} \times 100
$$

where $\mathrm{W}$ represented weight and $\left(\mathrm{t}_{2}-\mathrm{t}_{1}\right)$ the interval between the 2 considered samples.

A Condition Index (CI) was then calculated for all oysters from DMW and shell weight (SW) using the following equation (Walne \& Mann 1975):

$$
\mathrm{CI}=\frac{\mathrm{DMW}(\mathrm{mg})}{\mathrm{SW}(\mathrm{g})}
$$

Another condition index, MI (Meat Index), commonly used by French scientists and oyster farmers, was calculated as follows:

$$
\mathrm{MI}=\frac{\mathrm{WMW}}{\mathrm{WW}} \times 100
$$

The SMI (based on the appearance of the flesh of 30 oysters per sampling date and site) was complemented by a histological study carried out on a smaller number of half-grown and market-sized oysters. At every sampling date for batches B and $\mathrm{C}$ respectively, 25 (5 per each of the 5 sites) and 30 individuals (10 per 3 sites: GR1, CB, and GE3) were used for microscopic histological examination. Cross sections from oysters were cut behind the labial palps and $5 \mathrm{~mm}$-thick sections were fixed in Davidson fluid. These were then routinely processed for histology and $5-\mu \mathrm{m}$ paraffin-imbedded sections were stained according to the trichrome protocol of Prenant Gabe (Gabe 1968). Each individual was classified into distinct phases of gonadal maturation based on microscopic analysis and according to Lubet modified classification (1959) (see Costil et al. 2005 for details). Briefly, stage I corresponds to gonial multiplication in tubules, which are poorly developed (IR differing from I by the presence of at least $50 \%$ of residual gametes of the previous reproductive cycle). During stage II gonadal tubules highly develop, whereas vitellogenesis occurs in females and various kinds of sexual cells can be observed in males. Stage III is associated with maximum gonad size and includes 3 substages: IIIA (stalk oocytes and oocytes still in the process of vitellogenesis/all male cell categories including spermatozoa), IIIB (oysters are ready to spawn or only limited spawning has occurred) and IIID (highly or totally spent; postspawning and resorption stage).

\section{Statistical and Multivariate Analysis}

To test for significant differences of each biological parameter among sites or among batches, several methods were used depending on the type of variable (measures or frequencies) and the normality of data sets (Scherrer 1984). One way ANOVAs were applied to the data (transformed or not) having met the assumptions of the test. When the data were still heterogeneous after transformation, nonparametric tests (Kruskal-Wallis) were used. In both cases multiple comparison tests (Student Newman Keuls) were then undertaken to distinguish different groups. Chi-square tests were performed to compare frequencies. These analyses were conducted with Statgraphics Plus 4.0 software.

Multivariate descriptive techniques were used to synthesize the large data sets and to construct clusters characterized by explanatory (quantitative) variables and additional qualitative variables (Escofier \& Pages 1990). Initially a principal component analysis (PCA) was performed, and subsequently a hierarchical ascending clustering (HAC), using Ward criterion, was carried out on main factorial coordinates. These analyses were performed using SPAD.N software (Lebart et al. 1996).

\section{RESULTS}

\section{Mortality}

Mean daily mortality through the entire rearing period showed high seasonal and spatial variations (Fig. 2). The first substantial mortalities in each batch were observed at the start of the rearing until May. These mortalities could be attributed to an acclimatization phenomenon. Subsequently, the greatest range of oyster mortality rates occurred in the summer period (July to September or October). Apart from these periods, the mortality was relatively constant, fluctuating between 0 and $0.08 \%$ day $^{-1}$. Mortality rates were also characterized by marked
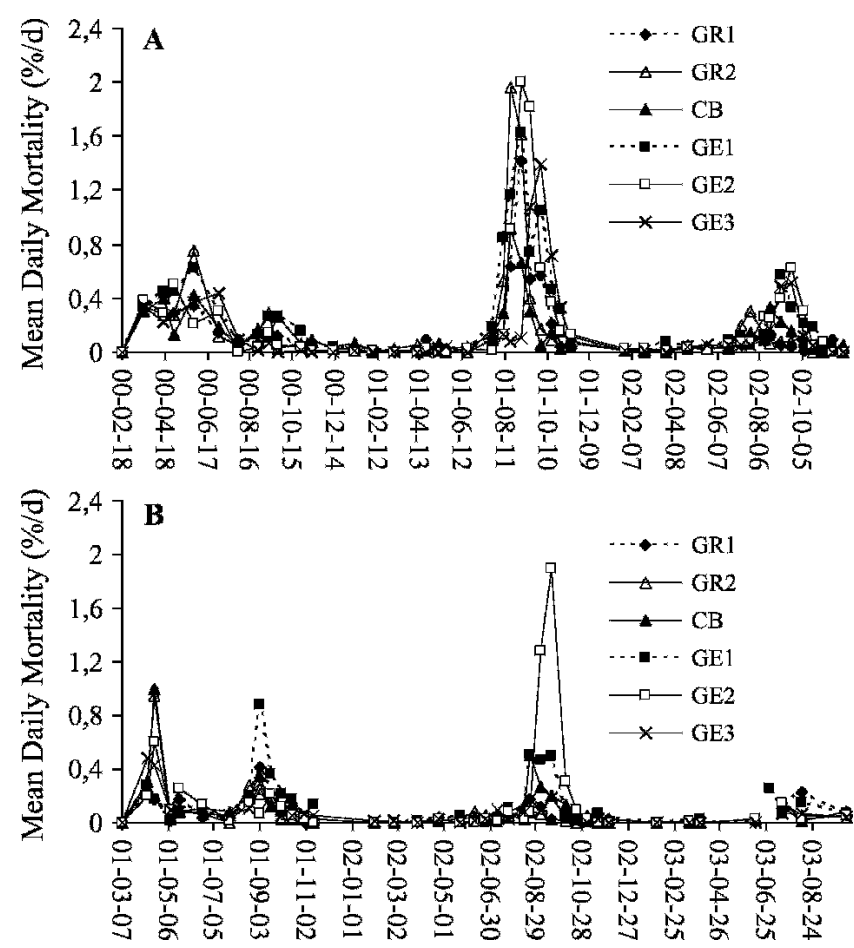

Figure 2. Seasonal and spatial variations of mean daily mortality $\left(\% \mathrm{day}^{-1}\right)$ in (a) batch B from February 2000 to December 2002 and (b) batch $\mathrm{C}$ from March 2001 to October 2003. 
interannual variations with the higher values observed in 2001 for batch B. A summary of the cumulative mortality is given for the three oyster stages in Table 1. At the end of the spat stage (one year study), mortality had already reached on average $44.49 \pm 5.50 \%$ in batch B and $31.21 \pm 4.02 \%$ in batch $\mathrm{C}$, the highest rate being recorded at station GE1 with $54.2 \%$ (B) and $37 \%$ (C). Cumulative rates attained $71.70 \%$ (B) and $44.62 \%(\mathrm{C})$ at the end of the half-grown stage and $77.51 \%$ (B) and $49.28 \%$ (C) at the end of the study. After the three years of study, the oysters experiencing the greatest mortality were located at two stations of the Gefosse area (GE1 and GE2).

Considering the acclimatization period, the daily mortality was on average, respectively for batches B and C, 0.34 and $0.22 \%$ day $^{-1}$ (Table 2). Mean rates by site were comprised between $0.29(\mathrm{CB})$ and $0.44(\mathrm{GE} 1) \% \mathrm{day}^{-1}$ for batch $\mathrm{B}$ and between 0.14 (GR1 and GE1) and 0.35 (GR2 and CB) $\%$ day $^{-1}$ for batch $\mathrm{C}$. At the end of this period, mean cumulative mortality attained $23.80 \%$ (Batch B) and 14.08\% (Batch C). A two-way ANOVA test carried out on this acclimatization period showed insignificant site $(P=0.88)$ and insignificant batch $(P=0.15)$ effects on daily oyster mortality. However, in terms of cumulative mortality, the oysters from batch B experienced higher mortality (Kruskal-Wallis; $P=0.01$ ) at the end of acclimatization period.

Summer mortalities greatly varied according to years and batches. Mean rates (over the whole summer period) ranged from $0.08 \pm 0.03 \% \mathrm{day}^{-1}$ (batch C, 2003) to $0.52 \pm 0.55 \% \mathrm{day}^{-1}$ (batch B, 2001) (Fig. 2). Tests were performed on daily mortalities in 2001 and 2002 to identify the effect of the age-class. Results showed that, in 2001, spat (C) was significantly less affected than half-grown (B) oysters (Kruskal-Wallis, $P<$ 0.0001 ) and, in 2002, half-grown oysters (C) exhibited higher mortality than marketable (B) oysters (Kruskal-Wallis, $P<$ 0.05). In 2001, cumulative percentages calculated on the summer period, indicate that mortality was, on average, much greater in half-grown than in spat oysters (Table 3). In 2002, the difference between half-grown and marketable oysters was less pronounced. In view of previous results, the comparison of daily mortalities between years was performed independently for each age-class. The mortality rates were similar for spat oysters in 2000 (B) and 2001 (C) (Kruskal-Wallis, $P=0.65$ ), and for marketable oysters in 2002 (B) and 2003 (C) (KruskalWallis, $P=0.43$ ), whereas they were significantly higher for half-grown oyster in 2001 (B) than 2002 (C) (Kruskal-Wallis, $P<0.001)$. The year 2001 seems to have been an exceptional year in terms of mortality, particularly for oysters in their second year of life. The cumulative percentage of mortality (Table 3) ranged from 28.47 (CB) to 57.84 (GE1) and averaged $45.55 \pm 11.29$.

Figure 2 shows variations between sites during the summer period, but no significant differences of these daily mortalities were statistically detected (certainly because of a high variability of the intrasite values). However, for each summer, the maximal values were recorded in GE1 (C, 2001: 0.89\% day $^{-1}$; C, 2003: 0.25\% day $^{-1}$ ), GE2 (B, 2001: 2.01\% day ${ }^{-1}$; B, 2002: $0.62 \%$ day $^{-1}$; C, 2002: $1.89 \%$ day $^{-1}$ ) or GE3 (B, 2000: $0.44 \%$ day $^{-1}$ ). Furthermore, considering the cumulative percentage (Table 3 ), oysters experienced highest mortalities in the Gefosse area, particularly in GE1 and GE2, for 3 consecutive years.

\section{GROWTH CONDITION AND REPRODUCTION}

\section{Shell Growth}

At the start of the biometric study, mean shell weight was $2.88 \pm 1.14 \mathrm{~g}(\mathrm{~B})$ and $5.17 \pm 2.25 \mathrm{~g}(\mathrm{C})$. After one year of rearing, it averaged $14.29 \pm 6.96 \mathrm{~g}(\mathrm{~B})$ and $16.27 \pm 7.83(\mathrm{C})$; after two years, it doubled; and at the end of the study it attained $50.92 \pm 22.90 \mathrm{~g}(\mathrm{~B})$ and $46.87 \pm 16.79 \mathrm{~g}$ (C) (Fig. 3). These last standard deviation values clearly indicate the high interindividual variation in growth.

Two-way ANOVA (sampling date and site) indicated a significant effect of time on shell growth in both batches $(P<$ 0.001). Moreover, the seasonal growth pattern was similar between years. Oysters grew fastest during the June to September sampling period, irrespective of locale. Shell growth slowed or ceased during the colder autumn to winter period and increased in the following spring. It also seems that shell weight occasionally decreased slightly. This may have been caused by handling damage to the delicate shell newly grown in spring. As expected, mean daily growth rates greatly diminished with oyster age (Table 4$)$.

The effect of the factor site was also highly significant (ANOVA; $P<0.001$ ) for the shell weight in both batches. The SNK test revealed that GE3 supported the least growth, whereas shell growth was similar at the four other sites. Mean daily growth rates also indicated a slower growth at GE3, with on average $0.77 \% \mathrm{day}^{-1}(\mathrm{~B})$ and $0.66 \% \mathrm{day}^{-1}(\mathrm{C})$. However, these rates were statistically equivalent at the five stations (Kruskal-Wallis; $P=0.57[\mathrm{~B}]$ and $P=0.70[\mathrm{C}]$ ), probably because of large intrasite variations.

TABLE 1.

Cumulative mortality (in percentage) for oysters from batches B and C. ( \pm standard deviation).

\begin{tabular}{|c|c|c|c|c|c|c|}
\hline \multirow[b]{2}{*}{ Sites } & \multicolumn{3}{|c|}{ Batch B } & \multicolumn{3}{|c|}{ Batch C } \\
\hline & After 1 Year & After 2 Years & End of the Study & After 1 Year & After 2 Years & End of the Study \\
\hline GR1 & 41.69 & 66.22 & 70.22 & 26.40 & 34.32 & 41.47 \\
\hline GR2 & 46.72 & 74.68 & 79.07 & 30.93 & 36.49 & 40.33 \\
\hline $\mathrm{CB}$ & 44.77 & 64.05 & 70.39 & 33.52 & 46.80 & 51.29 \\
\hline GE1 & 54.17 & 82.20 & 87.32 & 36.97 & 51.21 & 57.40 \\
\hline GE2 & 39.36 & 74.87 & 82.49 & 27.03 & 59.19 & 62.49 \\
\hline GE3 & 40.23 & 68.15 & 75.56 & 32.43 & 39.72 & 42.68 \\
\hline Average & $44.49 \pm 5.50$ & $71.70 \pm 6.79$ & $77.51 \pm 6.80$ & $31.21 \pm 4.02$ & $44.62 \pm 9.56$ & $49.28 \pm 9.26$ \\
\hline
\end{tabular}


TABLE 2.

Acclimatization mortality: mean daily mortality $\left(\% \mathrm{day}^{-1}\right)$ and cumulative mortality (\%) of oysters during the periods FebruaryMay 2000 for batch B and March-May 2001 for batch C. ( \pm standard deviation).

\begin{tabular}{|c|c|c|c|c|}
\hline \multirow[b]{2}{*}{ Sites } & \multicolumn{2}{|c|}{$\begin{array}{c}\text { Mean Daily } \\
{\text { Mortality }\left(\% . \text { day }^{-1}\right)}^{-1}\end{array}$} & \multicolumn{2}{|c|}{$\begin{array}{c}\text { Cumulative Mortality } \\
\text { (in \%) }\end{array}$} \\
\hline & Batch B & Batch C & Batch B & Batch C \\
\hline GR1 & $0.31 \pm 0.11$ & $0.14 \pm 0.11$ & 23.09 & 8.51 \\
\hline GR2 & $0.35 \pm 0.24$ & $0.35 \pm 0.44$ & 28.20 & 17.03 \\
\hline $\mathrm{CB}$ & $0.29 \pm 0.13$ & $0.35 \pm 0.46$ & 22.23 & 16.74 \\
\hline GE1 & $0.44 \pm 0.12$ & $0.14 \pm 0.13$ & 30.88 & 10.35 \\
\hline GE2 & $0.34 \pm 0.11$ & $0.29 \pm 0.26$ & 19.58 & 12.65 \\
\hline GE3 & $0.33 \pm 0.09$ & $0.27 \pm 0.24$ & 18.78 & 19.19 \\
\hline Average & $0.34 \pm 0.14$ & $0.22 \pm 0.29$ & $23.80 \pm 4.81$ & $14.08 \pm 4.21$ \\
\hline
\end{tabular}

\section{Tissue Growth}

Tissue growth showed a different pattern from shell growth with marked seasonal variations (Fig. 4). Wet meat weight seasonally varied according to the reproductive cycle of oysters, with an increase in spring and early summer, a drop in summer (in juvenile oysters) or early autumn (in spat oysters), and a relative cessation in most cases during winter. These changes corresponded respectively to sexual maturation, spawning (and/or resorption of gametes), and reorganization of the gonad. In both batches, there was a significant difference in meat weight of oysters among sites (ANOVA, $P<0.001$ ). The SNK test showed that meat growth at GE2 exceeded on average that of oysters at other sites, with GE3 showing the lowest mean weight. In batch $\mathrm{C}$, at $\mathrm{CB}$; GE1; and GE2, meat weight increased again after spawning in early autumn and then decreased during winter.

\section{Condition and Sexual Maturity Indexes}

Oysters displayed very high condition indices with maximal values attaining on average 119 (B) and 124 (C) at GE2 in summer (July). As for wet meat weight, the condition index fluctuated interannually and seasonally according to reproductive cycle (Fig. 5). Overall, it was maximal in summer during full maturity, drastically decreased at the end of summer when spawning occurred, and remained low in winter when the oysters reinitiated a new reproductive cycle. ANOVA indicated significant differences between sites $(P<0.001)$. Oysters from GE2 consistently exhibited a higher condition index than those at the other stations (SNK test). Moreover, spawning and/or resorption occurred differently between sites and between years. For batch B in 2000, the decline of the index began earlier at GR1, CB, and GE1 than at the Gefosse sites GE2 and GE3, but in 2001 an opposite result was obtained because the decrease was later at Grandcamp. In batch $\mathrm{C}$, a marked decrease of CI tended to occur in oysters at Grandcamp and at $\mathrm{CB}$ before those from the Gefosse area. Furthermore, the sexual maturity index, estimated in juvenile and market-sized oysters, confirmed these observations. For batch $\mathrm{C}$, chi-square tests showed that the sexual maturity index (SMI) 1.5 predominated in GR1 and $\mathrm{CB}$, whereas SMI 2 was dominant at Gefosse sites (including GE3) in August 2002 (just after first spawning occurred). In contrast, for batch B in September 2001, SMI 1 and 1.5 were in the majority at GE2 and GE3, whereas SMI 2 was still largely predominant at GR1, CB, and GE1. For both batches, these SMI results are supported by the histological study carried out on half-grown oysters (Fig. 6). At the end of the reproductive cycle, SMI 2 generally corresponded to stage IIIB (or early IIID) and SMI 1.5 to stage IIID. Stages I or IR (corresponding to the beginning of a new reproductive cycle) appeared more variable according to the extent of spawning and/or resorption of the previous reproductive cycle. The reproductive cycle did not differ significantly between oysters placed at the different sites $\left(\chi^{2}\right.$ tests; $\left.P>0.05\right)$ except during the postspawning and/or resorption period. Outside this period and regardless of which site was considered, the reproductive cycle of both batches thus followed the overall chronology already described in the Bay of Veys by Costil et al. (2005): stage I from SeptemberOctober to March-April (and which is exclusive in December), stage II from January to May (when this is the only stage observed), stage IIIA appearing in June in the most precocious oysters and a mixture of stages IIIA (quite fleeting), and more especially IIIB and IIID from July to October-November.

\section{Synthesis Based on Multivariate Analysis}

For each batch, the biometric data set (10 quantitative variables) was used as a matrix for a principal component analysis (PCA) followed by a hierarchical ascending clustering (HAC) to analyze relationships between variables and to

TABLE 3.

Summer mortality: cumulative mortality (\%) during the summer period in 2000, 2001, 2002, and 2003 for batches B and C. ( \pm standard deviation).

\begin{tabular}{|c|c|c|c|c|c|c|}
\hline \multirow[b]{2}{*}{ Sites } & \multicolumn{3}{|c|}{ Batch B } & \multicolumn{3}{|c|}{ Batch C } \\
\hline & 2000 & 2001 & 2002 & 2001 & 2002 & 2003 \\
\hline GR1 & 6.50 & 38.87 & 5.86 & 15.66 & 7.11 & 10.58 \\
\hline GR2 & 9.98 & 48.63 & 10.67 & 13.65 & 4.26 & 6.04 \\
\hline $\mathrm{CB}$ & 11.50 & 28.47 & 12.75 & 14.29 & 16.70 & 6.88 \\
\hline GE1 & 15.07 & 57.84 & 21.12 & 26.30 & 19.96 & 8.12 \\
\hline GE2 & 4.91 & 57.01 & 25.56 & 10.00 & 42.76 & 6.20 \\
\hline GE3 & 1.99 & 42.47 & 19.30 & 10.86 & 9.29 & 4.60 \\
\hline Average & $8.33 \pm 4.76$ & $45.55 \pm 11.29$ & $15.88 \pm 7.35$ & $15.13 \pm 5.87$ & $16.68 \pm 14.08$ & $7.07 \pm 2.07$ \\
\hline
\end{tabular}



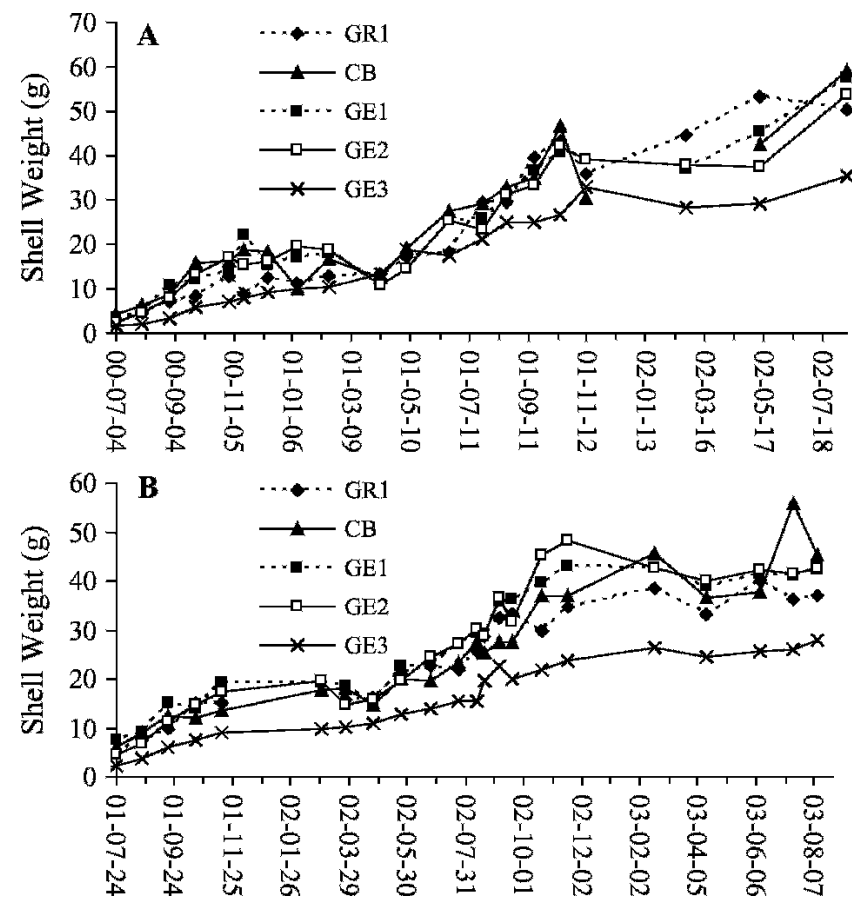

Figure 3. Seasonal and spatial variations of mean shell weight (g) in (a) batch $B$ from February 2000 to August 2002 and (b) batch $C$ from March 2001 to August 2003.

determine clusters of individuals. Results of these analyses were similar in both batches. The two first factors appeared relevant because they represent $91.50 \%$ (batch B) and $91.66 \%$ (batch C) of the total variance. Factor 1 showed a "size effect" (coordinates all negative) because of the high correlation between all of the variables (Table 5). This factor was mainly explained by meat weight, whole weight, dry meat weight, and shell weight; whereas factor 2 was best explained by meat and condition indices. Factor 2 split the variables in two: variables relative to soft tissue (positive coordinates) and variables relative to shell (negative coordinates). The HAC, performed on the two first factors, led to the formation of 4 clusters in both batches with a high ratio of intercluster inertia/total inertia reaching 0.73 (batch B) and 0.69 (batch C). Additional qualitative variables and the barycentre of each cluster are illustrated on the principal plane in Figure 7, and the character- istics of each cluster are indicated in Table 6 (B) and Table 7 (C). The study chronology was easily distinguishable, because it followed shell and meat growth and different groups of months appeared corresponding to the various stages of growth and reproduction described previously. Null and low mortalities (classes $0-3$ ) were regrouped and corresponded to the young animals (low weights) by contrast to the highest mortalities (class 4 or class 5), which corresponded to older oysters and were associated with summer months. With regard to study stations, they were split into 3 different clusters summarizing their main biological parameters. GE3 belonged to cluster 1, which was characterized by low meat and shell growth but a relatively high condition index. GR1 and $\mathrm{CB}$ illustrated cluster 2 and were mainly characterized by low condition index. GE2, belonging to cluster 3, was associated with high condition index and high meat growth. GE1 also belonged to cluster 3 but its position on the plane slightly varied between batches $\mathrm{B}$ and $\mathrm{C}$, revealing intermediate biological performances between GE2 and GR1-CB.

\section{DISCUSSION}

\section{Growth, Condition, and Reproduction}

Our results on growth and condition are coherent with the study of juvenile oysters deployed in 2000 at the same sites within the Bay of Veys (Costil et al. 2005). They are also in accordance with the observations of the French monitoring network "REMORA" performed by IFREMER (Fleury et al. 2003) and confirm the quality of Crassostrea gigas from the Bay of Veys, as measured by meat weight and condition index, in comparison with other French oyster-rearing areas. In this bay, the oysters belong to the best commercial category ("special") with a mean wet meat weight/whole weight always greater than 10.5. Moreover, condition indices were globally high compared with other countries. The condition index for C. gigas from the Bay of Veys attained similar maximal values as those recorded from C. gigas in Canada (Brown \& Hartwick 1988b), but were much higher than that recorded for $C$. virginica in Canada (Bataller et al. 1999) and C. gigas in South Africa (Robinson et al. 2005) and in Portugal (Almeida et al. 1999). This confirmed the high productivity of the Bay of Veys.

In spite of large differences between individuals in growth parameters, the typical pattern of growth of temperate water

TABLE 4

Mean growth rate $\left(\% \mathrm{day}^{-1}\right)$ of shell weight of spat (first year), half-grown (second year) and market-sized (third year) oysters at the five study sites (GR1-GE3). ( \pm standard deviation).

\begin{tabular}{lccccrr}
\hline \hline & GR1 & CB & GE1 & GE2 & GE3 & All Sites \\
\hline Batch B & & & & & & \\
$\quad$ Spat & $1.33 \pm 0.60$ & $1.36 \pm 0.66$ & $1.31 \pm 1.04$ & $1.41 \pm 0.82$ & $1.02 \pm 0.65$ & $1.25 \pm 0.71$ \\
Half-grown & $0.65 \pm 0.48$ & $0.71 \pm 0.53$ & $0.61 \pm 0.36$ & $0.89 \pm 0.36$ & $0.55 \pm 0.37$ & $0.64 \pm 0.29$ \\
Marketable & $0.22 \pm 0.01$ & $0.36 \pm 0.01$ & $0.26 \pm 0.01$ & $0.40 \pm 0.01$ & $0.13 \pm 0.09$ & $0.15 \pm 0.06$ \\
$\quad$ Average & $0.98 \pm 0.67$ & $1.03 \pm 0.67$ & $0.98 \pm 0.91$ & $1.18 \pm 0.75$ & $0.77 \pm 0.61$ & $0.88 \pm 0.69$ \\
Batch C & & & & & & \\
Spat & $1.42 \pm 0.71$ & $1.33 \pm 0.79$ & $1.42 \pm 0.96$ & $1.41 \pm 0.70$ & $1.11 \pm 0.60$ & $1.35 \pm 0.62$ \\
Half-grown & $0.62 \pm 0.43$ & $0.82 \pm 0.29$ & $0.54 \pm 0.53$ & $0.89 \pm 0.45$ & $0.50 \pm 0.78$ & $0.60 \pm 0.32$ \\
Marketable & $0.17 \pm 0.11$ & $0.48 \pm 0.49$ & $0.07 \pm 0.06$ & $0.09 \pm 0.01$ & $0.12 \pm 0.07$ & $0.13 \pm 0.07$ \\
Average & $0.89 \pm 0.72$ & $1.00 \pm 0.73$ & $0.93 \pm 0.90$ & $0.93 \pm 0.69$ & $0.66 \pm 0.71$ & $0.79 \pm 0.62$ \\
\hline & & & & & &
\end{tabular}



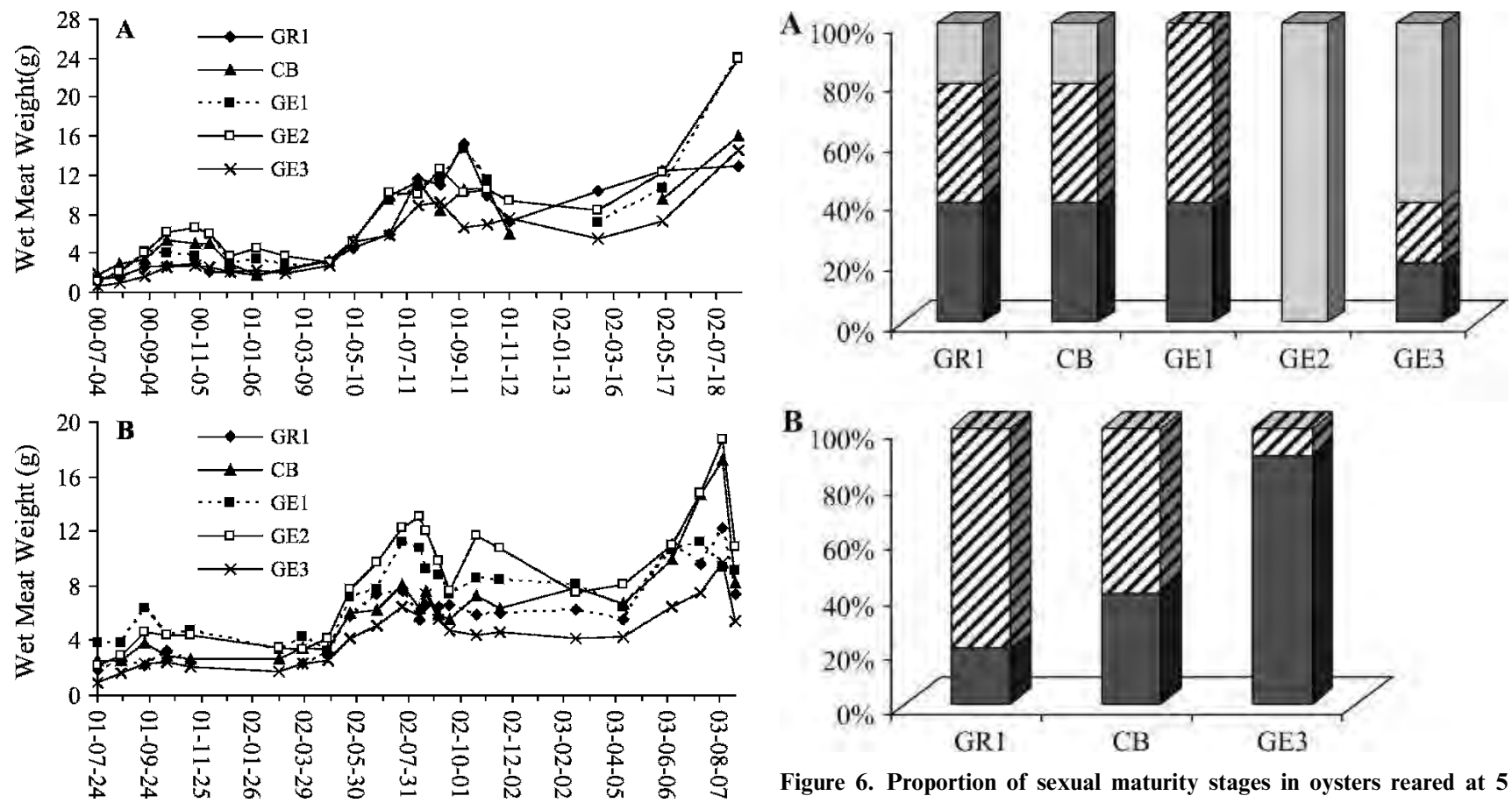

Figure 4. Seasonal and spatial variations of mean wet meat weight $(\mathrm{g})$ in (a) batch B from February 2000 to August 2002 and (b) batch $C$ from March 2001 to August 2003.

bivalve species (Quayle \& Newkirk 1989) is described in the present study. Most shell growth occurred over spring and summer months with a plateau during the winter months as commonly observed in French oyster banks (Soletchnik et al.
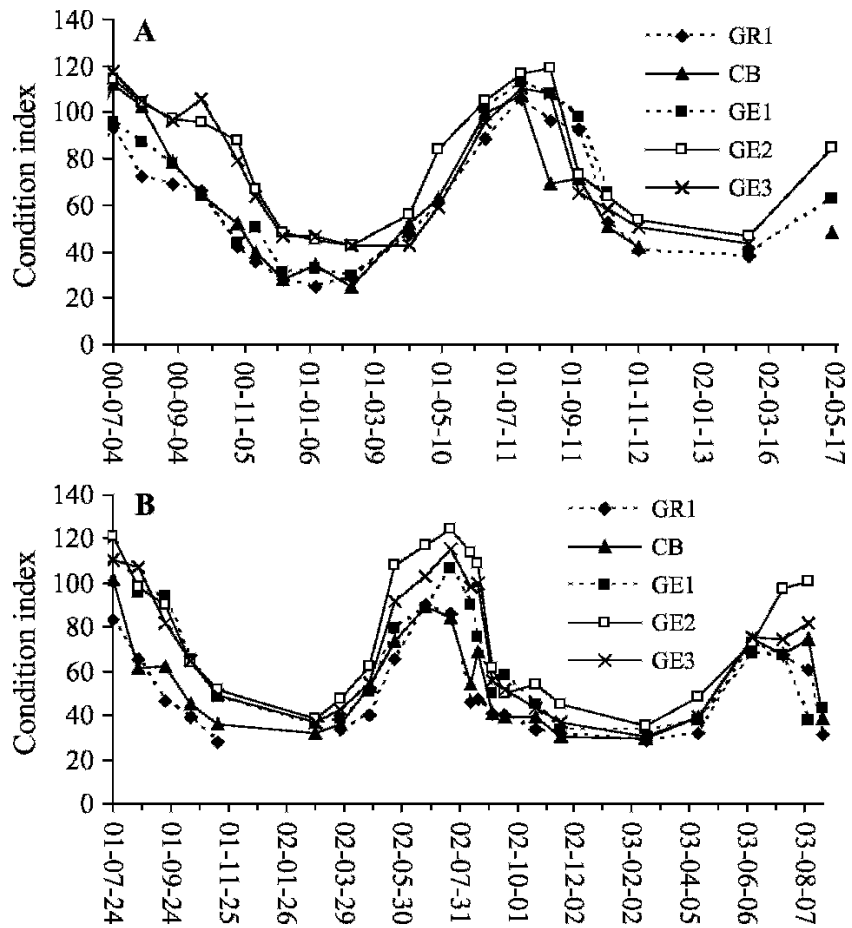

Figure 5. Seasonal and spatial variations of mean condition index in (a) batch B from February 2000 to August 2002 and (b) batch C from March 2001 to August 2003.

Figure 6. Proportion of sexual maturity stages in oysters reared at 5 stations (GR1, CB, GE1, GE2 \& GE3) for batch B on 17 September 2001 and at 3 stations (GR1, CB, \& GE3) for batch $\mathrm{C}$ on 13 August 2002. For maturity stage description see text. $\square$ Stages I + IR; $Z$, Stage III D; 口, Stage III B.

2002, Costil et al. 2005), in Ireland (Wilson 1987), in Portugal (Almeida et al. 1997), and in Tasmania (Mitchell et al. 2000). Tissue weight did not show the same growth profile, as reflected by the observed decrease in summer because of spawning. However, in spring a rapid increase of growth was evident from tissue and shell measurements. Seasonal variations in growth can be explained by environmental changes and likely the synergistic effect of temperature and food supply (Brown \& Hartwick 1988a, Cano et al. 1997). In the Bay of Veys, the marked increase in weight from spring was attributable to the increase of temperature and the availability of phytoplankton, which mainly blooms in early spring (Jouenne et al. 2007). Oysters showed similar patterns of change in dry meat weight throughout the three years, although differences in growth rates were noticed between the years. Observed differences between years were attributable both to interannual variability in

TABLE 5.

Factor loadings of the Principal Component Analysis (PCA) performed on data set of batches $B$ and $C$.

\begin{tabular}{lccccc}
\hline \hline & \multicolumn{2}{c}{ Batch B } & & \multicolumn{2}{c}{ Batch C } \\
\cline { 2 - 3 } \cline { 5 - 6 } Variable & Axe 1 & Axe 2 & & Axe 1 & Axe 2 \\
\hline L & -0.88 & -0.25 & & -0.87 & -0.10 \\
W & -0.87 & -0.13 & & -0.89 & -0.24 \\
WW & -0.96 & -0.21 & -0.96 & -0.21 \\
SW & -0.94 & -0.24 & -0.94 & -0.24 \\
WMW & -0.97 & 0.17 & & -0.94 & 0.28 \\
DMW & -0.94 & 0.24 & & -0.87 & 0.42 \\
WM & -0.18 & 0.96 & & -0.06 & 0.97 \\
Meat Index & -0.20 & 0.95 & & -0.04 & 0.98 \\
\hline
\end{tabular}



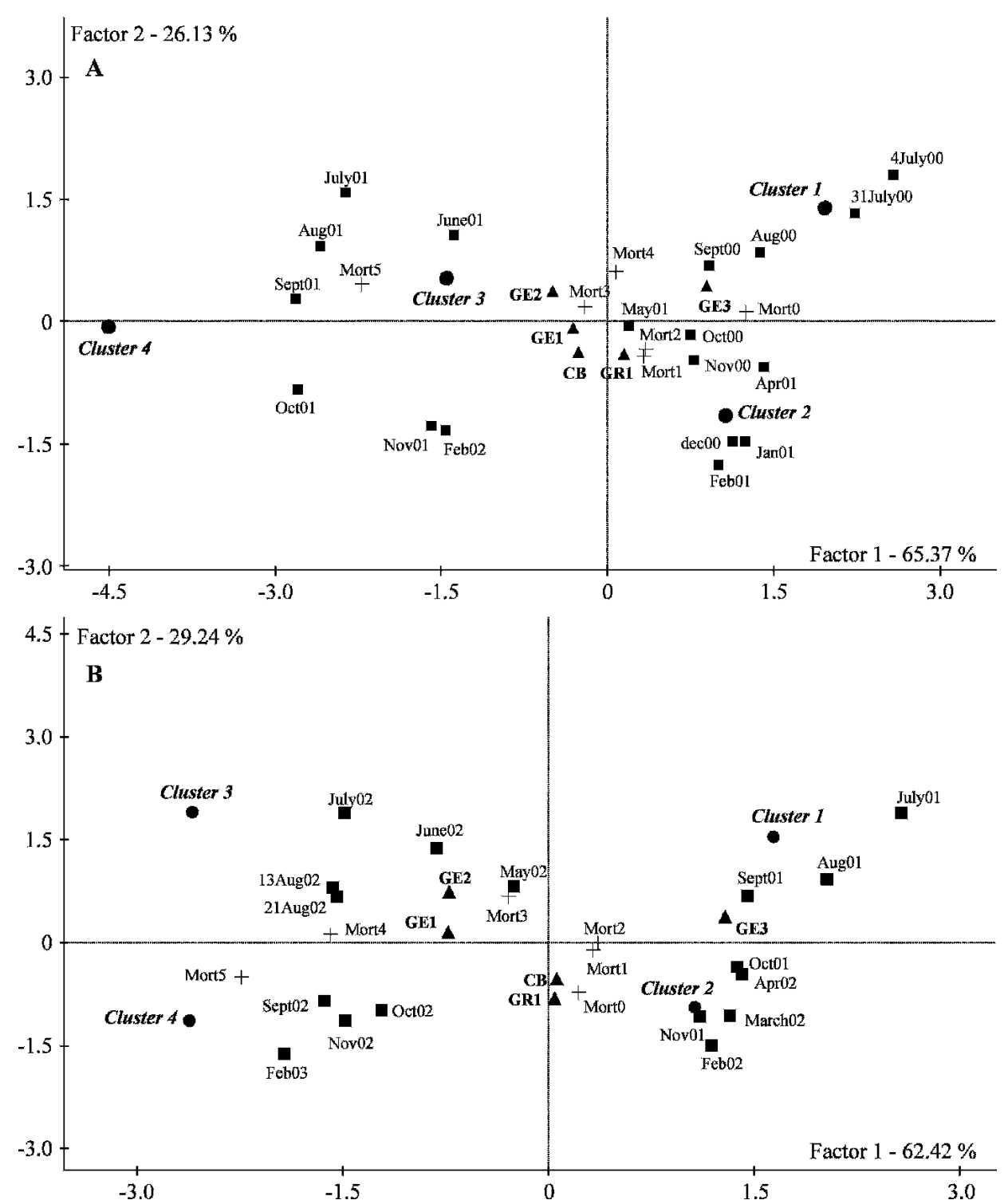

Figure 7. Representation of the illustrative variable modalities and cluster barycentres on the two first factorial axes obtained with the successive multivariate analysis (Principal Component Analysis and Hierarchical Ascendent Classification). Mort. = Mortality class (expressed by mean daily rates).

environmental conditions and to an age effect. Shell growth rate showed a progressive decrease with age, as previously observed in many studies on different oyster species (Bataller et al. 1999, Mitchell et al. 2000, Pouvreau et al. 2000). This decrease with age is strongly linked with the progressive investment in reproduction, because energy, which is allocated to reproduction (called the reproductive effort) is lost for shell and somatic tissue growth (Pouvreau et al. 2000). Therefore, the increase of meat weight in "adult" oysters in contrast to the increase in spat may be attributable to a higher production of reproductive tissue. Heral (1989) estimated that the proportion of total production expended on gamete output in the Pacific oyster rose from $18 \%$ in 1-y-old oysters to $84 \%$ in "adults" (3-y-old). The maximal values of the condition index (in summer) of the three age classes were similar in this study, and we can suggest the possibility that the proportion of somatic tissues is higher in younger oysters than in 2-y- and 3-y-old individuals. The seasonality of the condition index can be considered as reflecting the reproductive cycle of the oysters. Interannual variations between sites and age classes indicated a high variability in the timing of reproductive (essentially post spawning) events. This variability was also observed by Costil et al. (2005). The difference in the inflexion of the condition index curve, after the peak of full maturity, suggests various modalities of spawning between sites and years. In the Bay of Veys, spawning is always partial, but the extent varies (Costil et al. 2005). The more spawning is partial, the slower the condition index decreases reflecting the phenomenon of resorption of unspawned gametes, as described in Crassostrea gigas by Steele \& Mulcahy (1999).

Large scale geographic variability of biological characteristics is well known for Pacific oysters (Arakawa 1990), but microgeographic variations of growth and condition have also been observed in many oyster banks around the world, for 
TABLE 6.

Characterization of the clusters, determined by Hierarchical Ascending Clustering (HAC) for batch B, by the main biometric variables and the illustrative variables (month, site and mortality class).

\begin{tabular}{|c|c|c|c|c|}
\hline & Cluster 1 & Cluster 2 & Cluster 3 & Cluster 4 \\
\hline Number of individuals & 602 & 990 & 267 & 630 \\
\hline Shell weight ( $\sim$ whole weight) & Low & Intermediate & Intermediate to high & High \\
\hline Meat weight & Low & Intermediate & Intermediate to high & High \\
\hline Condition and meat index & Intermediates to high & Low & High & Intermediate \\
\hline Period & July-September 2000 & October 2000-May 2001 & June 2001-February 2002 & - \\
\hline Sites & GE3 & CB et GR1 & GE1 et GE2 & - \\
\hline Mortality class & - & $0 ;<0.04 ; 0.04-0.08$ & $0.08-0.16,0.16-0.32,>0.32$ & \\
\hline
\end{tabular}

example, in the Marennes Oléron Bay, France (Soletchnik et al. 1999), on the Portuguese coast (Almeida et al. 1997), in a Mexican Bay (Garcia-Esquivel et al. 2000), in Galveston Bay, USA (Soniat et al. 1989), and in British Colombia, Canada (Brown \& Hartwick 1988a, Brown \& Hartwick 1988b). In the Bay of Veys, overall trends in shell and tissue growth were similar among sites, but variations of biological parameters were also observed at a small spatial scale (about $3 \mathrm{~km}$ ). GE3 was characterized by the lowest shell weight compared with the four other sites, whereas tissue growth was greatest at GE2. Moreover, the high condition indices suggest that oysters at Gefosse had probably not only a higher somatic growth but also a greater gonad development corresponding to a greater reproductive effort. This variability suggests an ability of oysters to adapt their reproductive effort to their local environment (Enriquez-Diaz 2004). Site-specific differences in growth rates are likely associated with microgeographic differences in hydrological conditions within the Bay of Veys, because interannual or local differences in the energy storage cycle and reproduction of marine bivalves are often attributed to changes in environmental conditions (Kang et al. 2000, Ngo et al. 2005). At GE3, the time of immersion and consequently access to food is shorter ( $51 \%$ versus $72-79 \%$ at the other sites) (Costil et al. 2005), which may explain the lower shell growth. Differences in immersion time were small between the other sites, for which no significant differences in shell growth were recorded. However, differences in immersion time were not solely responsible for variations of tissue weight between sites. The high meat growth and condition indices at Gefosse (including GE3) may be attributed to an increased availability of food in the water column or different trophic resources compared with Grandcamp, linked to river input. Some authors have concluded that regional differences in oyster production effectively depend on the availability and distribution of phytoplankton, and organic matter (Soniat et al. 1989, Ngo et al. 2005). Almeida et al. (1997) showed that nutrient input associated with freshwater discharges from nearby river systems probably increased phytoplankton biomass and observed that oyster tissue weights were higher in estuarine areas compared with more marine stations. Brown and Hartwick (1988a) also attributed lower growth of shell height and dry meat weight (but not whole and shell weight) to an overall lower phytoplankton biomass. In South Africa, the lower condition index of oysters was believed to reflect decreased food supply (Robinson et al. 2005). However, in a Mediterranean Sea area condition indices were correlated mainly with temperature and, to a lesser extent, with dissolved oxygen, chlorophyll $a$ and suspended matter (Cano et al. 1997).

\section{Mortality}

In our study large seasonal, interannual, and interage variations of oyster mortality were observed. In 2001, mortalities were markedly higher than in other years and all batches and sites were affected by high mortality rates, up to $58 \%$, as in most of the professional stocks. By contrast, low rates were recorded in 2003, with cumulative values below $11 \%$. These observations suggest that temperature cannot be the only factor determining mortality, because 2003 was the warmer summer, and they confirm that other stresses must be associated with

TABLE 7.

Characterization of the clusters, determined by Hierarchical Ascending Clustering (HAC) for batch C, by the main biometric variables and the illustrative variables (month, site and mortality class).

\begin{tabular}{|c|c|c|c|c|}
\hline & Cluster 1 & Cluster 2 & Cluster 3 & Cluster 4 \\
\hline Number of individuals & 608 & 1083 & 308 & 432 \\
\hline $\begin{array}{l}\text { Shell weight } \\
\qquad(\sim \text { whole weight })\end{array}$ & Low & Intermediate & Intermediate to high & High \\
\hline Meat weight & Low & Intermediate & Intermediaire to high & High \\
\hline $\begin{array}{l}\text { Condition and meat } \\
\text { index }\end{array}$ & Intermediates to high & Low & High & Low \\
\hline Period & July-September 2001 & October 2001-April 2002 & May 2002-August 2002 & September 2002-February 2003 \\
\hline Sites & GE3 & $\mathrm{CB}$ et GR1 & GE1 et GE2 & - \\
\hline Mortality class & - & $0 ;<0.04 ; 0.04-0.08,0.16-0.32$ & $0.08-0.16$ & $>0.32$ \\
\hline
\end{tabular}


the phenomenon of summer mortality. Mortality was directly related to the temperature of seawater as observed by Lipovsky \& Chew (1972), but high temperature alone is probably not lethal. Cheney et al. (2000) demonstrated that oysters can survive repeated exposure to high temperatures (over $40^{\circ} \mathrm{C}$ ).

Mortality was negligible $(<5 \%)$ in spring and winter, except during the acclimatization period. Mortality increased in the summer when the gonad was most extensively developed and the mortality peak coincided with the spawning and postspawning periods when gonad volume began to decrease (IIIB and IIID). This result is coherent with the observations in 2000 and 2001 on juvenile and marketable oysters from another batch in the Bay of Veys (Costil et al. 2005). Mortality has been shown to be a postspawning phenomenon in other bivalve species, such as Ensis arcuatus (Fahy et al. 2002) and Mytilus edulis (Myrand et al. 2000). However, abnormal mortalities have also been recorded before the spawning process, coincident with full maturity and maximal gonad development in the MarennesOléron Bay (Soletchnik et al. 2005). In the Bay of Veys, the chronology of mortality events suggests that mortality is highly correlated to reproductive status and, in particular, that the process of spawning could be the most critical stage and constitute a physiological stress for oysters. The high energetic cost of reproductive processes is suspected to result in energetic deficiency (Mori 1965, Perdue et al. 1981, Soletchnik et al. 2005) and immuno-depression (Delaporte et al. 2006) and thus to be involved in summer mortality events by making oysters more susceptible to opportunistic pathogens and environmental stress. Delaporte et al. (2006) demonstrated that hemocyte parameters of oysters were more influenced by reproduction, related to seasonal temperature variation, than to food availability. They concluded that hemocyte functions may be perturbed by high reproductive effort, because during their experiment active gametogenesis resulted not only in a reduction of energy reserves but also in a reduction in the number of circulating hemocytes and in their adhesion capacity and phagocytic activity. Additionally, oysters showing the highest reproductive effort exhibited higher reactive oxygen species (ROS) production. After the main spawning event, some gametes are not released and the circulating hemocytes mobilized for gamete resorption are thus unavailable for immune functions. This mobilization varies according to the amount of gametes (and so reproduction effort) and the extent of spawning.

In the present study, marked variability in mortality patterns between age classes was also recorded: oysters suffered much higher mortalities in the second and third on-growing year than spat. The difference in mortality between age classes was greater when mortality was high. As a result, when summer mortality was low, the difference between age groups was not significant. In other French basins spat has been reported to have higher mortality rates than juvenile and marketable oysters (Soletchnik et al. 1999, Fleury et al. 2001). This difference between French basins indicates that the causes of mortality are variable and somewhat specific to each area. Age is thus an important factor in the mortality events, and all age groups of oysters were not equally affected. This suggests that there was no single physical cause of death, and physiological factors were likely involved. In contrast, no difference of reproductive characteristics was observed between age groups, either in the chronology of spawning events or in maximal condition indices achieved. Nevertheless, it is possible that the variables measured and the observations made in the present study were not suitable for distinguishing minor (but significant) differences in reproductive strategies between age classes. In particular, spat may have a lower reproductive effort or a different gametogenetic process that requires accurate analysis such as quantitative histology (histology coupled with image analysis) or ELISA test to qualify or quantify gonad development (Royer et al. submitted).

Mortality was higher at Gefosse than at Grancamp, as observed in another batch by Costil et al. (2005). A similar situation in Spain, where mortality was greater at a more estuarine station, was reported by Almeida et al. (1997). Levels and variability of condition indices suggest high reproductive effort and slower gamete resorption at Gefosse. In contrast, spawning generally occurred precociously in the Grandcamp area (except for batch B in 2001). Thus, the intensity of mortality appears to have been correlated with the investment of oysters in reproduction and with the process of spawning and/or gamete resorption. Enriquez-Diaz (2004) showed experimentally that oysters maintained in high trophic conditions had the highest reproductive effort and appeared to have some difficulties in spawning.

Our results have demonstrated the complexity of explaining the summer mortality of oysters in the Bay of Veys and the underlying exogenous and endogenous causes. Chronology and spatial variations of mortality highlight the critical timing and confirm that mass mortalities may be closely linked to reproduction. Increased mortality seems to be associated with a high reproductive effort, partial spawning, and /or slow gonadal resorption. To the physiological stress related to the reproductive status could be added other environmental factors that may be direct or indirect via reproduction. Temperature is a key component in the determinism of mass mortalities; it acts on timing of mortalities because it is closely correlated to reproductive status, the maturation of oyster germ cells being a function of temperature (Fabioux et al. 2005). Results from the MOREST project indicate $19^{\circ} \mathrm{C}$ as a threshold temperature above which mortality occurred (Gagnaire et al. 2005). However, temperature may have a direct effect on oysters. Temperature makes oysters more susceptible to other stresses as it can influence their immune system (Gagnaire et al. 2005, Zhang et al. 2006), and it can increase the effect of pollutants such as toxic metals (Lannig et al. 2006).

In the Bay of Veys, spatial variations in environmental parameters suggest that oysters at the different study sites experience varying degrees of physiological stress. In particular, water quality differences that reflect the influence of freshwater input are associated with higher mortality at the Gefosse site. Such a hypothesis is plausible because some authors have already reported effects of water quality on bivalve mass mortality (Lipovsky \& Chew 1972, Cheney et al. 2000). In the Bay of Veys, these factors may have a cumulative effect on mortality resulting from interaction between reproduction and the environment. Trophic level could especially be an important factor influencing oyster mortality, because different authors showed that food supply is the major environmental parameter determining gonad proliferation in oysters (Kang et al. 2000, Enriquez-Diaz 2004). An experimental study demonstrated that oyster mortality was four to five times greater in nutrientenriched seawater (Lipovsky \& Chew 1972). The river is the main source of nutrients for the Bay of Veys, which is characterized by a high phytoplankton primary production 
(Jouenne et al. 2005). Although no significant differences of phytoplankton biomass were revealed between the North (Grandcamp) and South (Gefosse) stations, Lefebvre et al. (2006) showed that the food source for oysters was different between these two areas. Stable isotope ratio analysis indicated that phytoplankton contributed mainly to oyster diet at the North station, whereas the contribution of terrestrial detritus and microphytobenthos increased by up to $50 \%$ at the South station. This study also revealed a high concentration of suspended sediment and organic material from the river at Gefosse, impacting the quality and dynamics of the substratum. It is noteworthy that the substratum in the Gefosse area is muddier than at Grandcamp. Substratum type could represent another environmental risk for oysters through the potential release of toxic compounds such as ammonium and hydrogen sulphide. Even though one study revealed no differences in mortality of Crassostrea virginica reared at two elevations $(15 / 38 \mathrm{~cm})$ off the bottom (Grabowski et al. 2004), the effect of proximity to the sediment has clearly been shown to be important in other banks where higher mortality was recorded on-bottom than off-bottom (Bataller et al. 1999, Soletchnik et al. 1999, Soletchnik et al. 2005). Moreover, Costil et al. (2005) indicated variations of salinity profile between the Gefosse and Grandcamp areas and this chemical parameter may also have an impact on mortality. In California, the salinity regimen influenced mortality in triploid juvenile Crassostrea gigas and Crassostrea virginica (Calvo et al. 1999). Survivorship was negatively impacted by salinities below $20-25 \%$ in North Carolina (Grabowski et al. 2004). We can also not exclude the possibility that at Gefosse seawater may have been contaminated by river input with a substance deleterious to oysters. The catchment basin of the Bay of Veys constitutes an area of intensive agricultural activity (bovine rearing, truck farming, and corn cultivation), and the use of pesticides is common. These pollutants might be also a stress factor that could contribute to mortality if coupled with other risk factors.

The precise causes of oyster mass mortalities remain unclear but the present study underlines the spatio-temporal variability of these mortalities, which differ on a relatively small scale $(<3 \mathrm{~km})$. Moreover, these mortalities occur during summer and early autumn but vary according to year, probably in relation to environmental parameters. However these parameters alone cannot explain the mortalities in the Bay of Veys and, oyster susceptibility depends greatly on age class. The implication is that oyster physiology links the risk of mortality with reproduction and particularly with spawning and/or gonadal resorption. It seems thus that a high reproductive effort associated with partial spawning and low resorption are harmful for oyster survival.

\section{ACKNOWLEDGMENTS}

The authors thank the staff at the Laboratoire Environnement/Ressources de Normandie (IFREMER Port-en-Bessin) and the Laboratoire de Biologie et Biotechnologies Marines (Université de Caen Basse-Normandie) for technical facilities and help with the fieldwork. The authors also thank Mrs. and Mr. Guy Pourtier, shellfish farmers in the Bay of Veys, for providing their facilities. The authors are grateful to Ian Probert and Helen McCombie for their linguistic guidance. This work was supported by the Conseil Général du Calvados, the MOREST national project funded by Ifremer and the Régions Basse-Normandie, Bretagne, Pays de la Loire, PoitouCharentes.

\section{LITERATURE CITED}

Almeida, M. J., J. Machado \& J. Coimbra. 1997. Growth and biochemical composition of Crassostrea gigas (Thunberg) at three fishfarm earthen ponds. J. Shellfish Res. 16:455-462.

Almeida, M. J., J. Machado \& J. Coimbra. 1999. Growth and biochemical composition of Crassostrea gigas (Thunberg) and Ostrea edulis (Linne) in two estuaries from the North of Portugal. $J$. Shellfish Res. 18:139-146.

Arakawa, K. Y. 1990. Commercially important species of oysters in the world. Mar. Behav. Physiol. 17:1-13.

Bataller, E., A. D. Boghen \& M. D. Burt. 1999. Comparative growth of the eastern oyster Crassostrea virginica (Gmelin) reared at low and high salinities in New Brunswick, Canada. J. Shellfish Res. 18:107114.

Brown, J. R. \& E. B. Hartwick. 1988a. Influences of temperature, salinity and available food upon suspended culture of the Pacific oyster, Crassostrea gigas: I. Absolute and allometric growth. Aquaculture 70:231-251.

Brown, J. R. \& E. B. Hartwick. 1988b. Influences of temperature, salinity and available food upon suspended culture of the Pacific oyster, Crassostrea gigas: II. Condition index and survival. Aquaculture 70:253-267.

Calvo, G. W., M. W. Luckenbach, S. K. Allen \& E. M. Burreson. 1999. Comparative field study of Crassostrea gigas (Thunberg, 1793) and Crassostrea virginica (Gmelin, 1791) in relation to salinity in Virginia. J. Shellfish Res. 18:465-473.

Cano, J., J. Rosique \& J. Rocamora. 1997. Influence of environnemental parameters on reproduction of the european flat oyster (Ostrea edulis L.) in a coastal lagoon (Mar Menor, southeastern Spain). J. Moll. Stud. 63:187-196.
Cheney, D. P., B. F. MacDonald \& R. A. Elston. 2000. Summer mortality of Pacific oysters, Crassostrea gigas (Thunberg): Initial findings on multiple environmental stressors in Puget Sound, Washington, 1998. J. Shellfish Res. 19:353-359.

CNC (Comité National de la Conchyliculture). 2005. http://cnc-france. com/index.php?rub $=2 \&$ page $=11 \&$ type $=$ theme $\& i d=103$.

Costil, K., J. Royer, M. Ropert, P. Soletchnik \& M. Mathieu. 2005. Spatio-temporal variations in biological performances and summer mortality of the Pacific oyster Crassostrea gigas in Normandy (France). Helgoland Mar. Res. 59:286-300.

Delaporte, M., P. Soudant, C. Lambert, J. Moal, S. Pouvreau \& J. F. Samain. 2006. Impact of food availability on energy storage and defence related hemocyte parameters of the Pacific oyster Crassostrea gigas during an experimental reproductive cycle. Aquaculture 254:571-582.

Escofier, B. \& J. Pages. 1990. Analyses factorielles simples et multiples; objectifs, méthodes et interprétation. Dunod, editor. Paris. 267 pp.

Enriquez-Diaz, M. 2004. Variabilité et bioénergétique de la reproduction chez l'huître creuse Crassostrea gigas. Thèse de l'Université de Bretagne Occidentale, Brest, France. 193 pp.

Fabioux, C., A. Huvet, P. Le Souchu, M. Le Pennec \& S. Pouvreau. 2005. Temperature and photoperiod drive Crassostrea gigas reproductive internal clock. Aquaculture 250:458-470.

Fahy, E., M. L. Alcantara, M. Norman, R. Browne, V. Roantree \& N. Pfeiffer. 2002. Mortalities of Ensis arcuatus (Jeffreys) (Solenacea) in western Ireland. J. Shellfish Res. 21:29-32.

Fleury, P. G., E. Goyard, J. Mazurie, S. Claude, J. F. Bouget, A. Langlade \& Y. Le Coguic. 2001. The assessing of Pacific oyster 
(Crassostrea gigas) rearing performances by the IFREMER/ REMORA network: method and first results (1993-1998) in Brittany (France). Hydrobiologia 465:195-208.

Fleury, P. G., F. Cornette, S. Claude, H. Palvadeau, S. Robert, F. d'Amico, P. Le Gall, C. Vercelli \& S. Pien. 2003. Résultats des stations nationales REMORA (REseau Mollusques des Rendements Aquacoles; huîtres creuse), année 2002, IFREMER DRV/ RA-/RST/2003 04. 49 pp.

Frontier, S. 1993. Stratégies d'échantillonnage en écologie. Masson \& P.U.L., editors. Paris \& Québec. 494 pp.

Gabe, M. Techniques histologiques. Masson and Cie, editors. Paris. $1113 \mathrm{pp}$.

Gagnaire, B., H. Frouin, K. Moreau, H. Thomas-Guyon \& T. Renault. 2005. Effects of temperature and salinity on haemocyte activities of the Pacific oyster, Crassostrea gigas (Thunberg). Fish Shellfish Immunol. 20:536-547.

Garcia-Esquivel, Z., M. A. Gonzalez-Gomez, D. L. Gomez-Togo, M. S. Galindo-Bect \& M. Hernandez-Ayon. 2000. Microgeographic differences in growth, mortality, and biochemical composition of cultured pacific oysters (Crassostrea gigas) from San Quintin Bay, Mexico. J. Shellfish Res. 19:789-797.

Goulletquer, P., P. Soletchnik, O. Le Moine, D. Razet, P. Geairon, N. Faury \& S. Taillade. 1998. Summer mortality of the pacific cupped oyster Crassostrea gigas in the Bay of Marennes-Oléron (France). ICES, Lisbon CM. CC:14-20.

Grabowski, J. H., C. H. Peterson, S. P. Powers, D. Gaskill \& H. C. Summerson. 2004. Growth and survivorship of non-native (Crassostrea gigas and Crassostrea ariakensis) versus native eastern oysters (Crassostrea virginica). J. Shellfish Res. 23:781-793.

Héral, M. 1989. The traditional French oyster culture. In: Barnabe, editor. Aquaculture. Technique et Documentation Lavoisier, Paris, France. pp. 347-397.

Jouenne, F., S. Lefebvre, B. Véron \& Y. Lagadeuc. 2005. Biological and physicochemical factors controlling short-term variability in phytoplankton primary production and photosynthetic parameters in a macrotidal ecosystem (eastern English Channel). Estuar. Coast. Shelf. Sci. 65:421-439.

Jouenne, F., S. Lefebvre, B. Véron \& Y. Lagadeuc. 2007. Phytoplankton community structure and primary production in small intertidal estuarine-bay ecosystem (eastern English Channel, France). Mar. Biol. 151:805-825.

Kang, C. K., M. S. Park, P. Y. Lee, W. J. Choi \& W. C. Lee. 2000. Seasonal variations in condition, reproductive activity, and biochemical composition of the Pacific oyster, Crassostrea gigas (Thunberg), in suspended culture in two coastal bays of Korea J. Shellfish Res. 19:771-778.

Lannig, G., A. S. Cherkasov \& I. M. Sokolova. 2006. Temperaturedependent effects of cadmium on mitochondrial and whole-organism bioenergetics of oysters (Crassostrea virginica). Mar. Environ. Res. 62:S79-S82.

Lebart, L., A. Morineau, T. Lambert \& P. Pleuvret. 1996. SPAD Manuel de référence. CISIA \& CERESTA, editors.

Lefebvre, S., F. Jouenne, B. Véron, J.C. Marin-Leal, F. Orvain, K. Grangeré, K. Costil, J. Royer \& M. Ropert. 2006. Evidence for spatial heterogeneity of the trophic environment for the Pacific oyster in the Baie des Veys (Normandy France). World Aquaculture Society, Aqua 2006, May 9-13. Firenza, Italy.

Le Roux, F., M. Gay, C. Lambert, M. Waechter, S. Poubalanne, B. Chollet, J. L. Nicolas \& F. Berthe. 2002. Comparative analysis of Vibrio splendidus-related strains isolated during Crassostrea gigas mortality events. Aquat. Living Resour. 15:251-258.

Lipovsky, P. \& K. K. Chew. 1972. Mortality of pacific oysters (Crassostrea gigas); the influence of the temperature and enriched seawater on oyster survival. Proc. Nat. Shellfish Assoc. 62: $72-82$.

Mackin, J. G. 1961. Mortalities of oysters. Proc. Natl. Shellfish Assoc. 50:40-51
Mitchell, I. M., C. M. Crawford \& M. J. Rushton. 2000. Flat oyster (Ostrea angasi) growth and survival rates at Georges Bay, Tasmania (Australia). Aquaculture 191:309-321.

Mori, K., H. Tamate, T. Imai \& O. Itikawa. 1965. Studies on the mass mortality of the oyster in Matsushima Bay. Changes in the metabolism of lipids and glycogen of the oyster during the stages of sexual maturation and spawning. Bull. Tohoku Reg. Fish. Res. Lab. 25:66-68.

Myrand, B., H. Guderley \& J. H. Himmelman. 2000. Reproduction and summer mortality of blue mussels Mytilus edulis in the Magdalen Islands, southern Gulf of St. Lawrence. Mar. Ecol. Prog. Ser. 197:193-207.

Ngo, T. T. T., S.-G. Kang, D.-H. Kang, P. Sorgeloos \& K.-S. Choi. 2006. Effect of culture depth on the proximate composition and reproduction of the Pacific oyster, Crassostrea gigas from Gosung Bay, Korea. Aquaculture 253:712-720.

Perdue, J. A., J. H. Beattie \& K. K. Chew. 1981. Some relationships between gametogenic cycle and summer mortality phenomenon in the pacific oyster (Crassostrea gigas) in Washington State. J. Shellfish Res. 1:9-16.

Pouvreau, S., J. Tiapari, A. Gangnery, F. Lagarde, M. Garnier, H. Teissier, G. Haumani, D. Buestel \& A. Bodoy. 2000. Growth of the black-lip pearl oyster, Pinctada margaritifera, in suspended culture under hydrobiological conditions of Takapoto lagoon (French Polynesia). Aquaculture 184:133-154.

Quayle, D. B. \& G. F. Newkirk. 1989. Farming bivalve molluscs: methods for study and development. Baton Rouge, L.A: World Aquaculture Society. 294 pp.

Robinson, T. B., C. L. Griffiths, A. Tonin, P. Bloomer \& M. P. Hare 2005. Naturalized populations of oysters, Crassostrea gigas along the South African coast: Distribution, abundance and population structure. J. Shellfish Res. 24:443-450.

Royer, J., C. Seguineau, K-I. Park, S. Pouvreau, K-S. Choi, \& K. Costil. Submitted. Gametogenetic cycle and reproductive effort assessed by two methods in 3 age classes of Pacific oysters, Crassostrea gigas, reared in Normandy.

Scherrer, B. 1984. Biostatistique. Gaëtan Morin, editor. Montréal. $850 \mathrm{pp}$.

Soletchnik, P., O. Le Moine, N. Faury, D. Razet, P. Geairon \& P. Goulletquer. 1999. Summer mortality of the oyster in the Bay Marennes-Oleron: spatial variability of environmental and biology using a geographical information system (GIS). Aquat. Living Resour. 12:131-143.

Soletchnik, P., A. Huvet, O. Le Moine, D. Razet, P. Geairon, N. Faury, P. Goulletquer \& P. Boudry. 2002. A comparative field study of growth, survival and reproduction of Crassostrea gigas, $C$. angulata and their hybrids. Aquat. Living Resour. 15:243-250.

Soletchnik, P., C. Lambert \& K. Costil. 2005. Summer mortality of Crassostrea gigas (Thunberg) in relation to environmental rearing conditions. J. Shellfish Res. 24:197-207.

Soniat, T. M., L. E. Smith \& M. S. Brody. 1989. Mortality and condition of the American oyster in Galveston Bay, Texas. Contrib. Mar. Sci. 31:77-94.

Steele, S. \& M. F. Mulcahy. 1999. Gametogenesis of the oyster Crassostrea gigas in southern Ireland. J. Mar. Biol. Assoc. U.K. 79:673-686.

Walne, P. R. \& R. Mann. 1975. Growth and biochemical composition in Ostrea edulis and Crassostrea gigas. In: H. Barnes, editor. Proceedings 9th European Marine Biology Symposium. Aberdeen: Aberdeen University Press. pp. 587-607.

Wilson, J. H. 1987. Environmental parameters controlling growth of Ostrea edulis L. and Pecten maximus L. in suspended culture. Aquaculture 64:119-131.

Zhang, Z., X. Li, M. Vandepeer \& W. Zhao. 2006. Effects of water temperature and air exposure on the lysosomal membrane stability of hemocytes in Pacific oysters, Crassostrea gigas (Thunberg). Aquaculture 256:502-509. 